\title{
AN ECONOMIC INTERPRETATION OF NEOCLASSICAL MONOPOLY THEORY IN THE LIGHT OF AUSTRIAN SCHOOL
}

\author{
Andreas Stamate ${ }^{1}$
}

ABSTRACT: The paper summarizes the contributions of the neoclassical and Austrian school of thought in the field of monopoly theory arguing that the first uses non-operational concepts in describing the entrepreneur's actions on the market. The Austrian economic theory of free competition is the opposite of perfect and pure competition which is the model used in most of policy recommendations and also the intellectual legacy of neoclassicism. After proving that the monopoly price can't be scientifically determined and neither the consumer loss of welfare, the paper raises the issue whether public policy should intervene in a case of monopoly.

Key words: monopoly, property rights, monopoly price, utility, consumer

JEL classification: B53, D41, P14

\section{Introduction}

We define as free the market in which the governmental regulations are absent, because only that market is free by its very nature. The regulated or corrected market will not be a model for this analysis. One of the most disputed subjects on the agenda of any economist specialized in economic competition field or concerning authorities holding regulating powers, is monopoly. This is the situation or state of the market in which a firm, after exiting a period of sub competitive prices or dumping, eliminates its competition, achieves the position of monopoly and then abuses by its dominant position and raises the price (as a consequence of restricting the output sold) up to a level which will result in losses for the consumer. (Baumol \& Blinder, 1979, pp. 363) This is the neoclassical definition of monopoly and will represent the start point for a critique thereof from the perspective of the free competition theory which belongs to the intellectual tradition of the Austrian school of economics. Moreover, the present paper will try to make a clear distinction between the two market approaches by showing their scientific nature. There are few aspects which need clarification before starting the discussion.

The first and most important aspect is the principle of private property which states that any person has property on his body (self ownership) and on every capital or consumer goods which were appropriated by voluntary exchange (contracting). (Rothbard, 1978, pp.28) According to this principle, an aggression occurs whenever any person appropriates the body or the private property of another person without his or her consent. (Hoppe, 2010, pp.20) This is an outstanding necessary principle for the competition theory because, after all, competition is a transfer of ownership titles. So before discussing issue which implies ownership titles, we must have a theory of allocating ownership titles first.

The second aspect is a method proposal, in the sense that from the very beginning the analytical tool to use in the monopoly theory should not contain preconceptions without relevance for the economic science. The paper will follow the economic arguments, and not the social, political, legal or even technical (entrepreneurial) ones. As economists, we are forced to take into consideration the natural state of affairs, and not the present or any legal status-quo, because only in

\footnotetext{
${ }^{1}$ Bucharest Academy of Economic Studies, Department of International Business and Economics, Romania, email: andreas.stamate@rei.ase.ro
} 
this way can we remain as neutral as possible to values. We suppose that the market is the place where any transactions are voluntary, determined only by the deliberate actions of individuals or firms, according to the principle of private property as exposed. The loss of benefits which one may experience after an economic action voluntarily undertaken (and on a contract-base) will not be deemed an infringement if the contract was observed. According to this statement, "a higher price" or "restricted output" will not be an infringement, firstly because there is no aggression on the ownership titles, and secondly because by his actions the consumer validates a certain state of the market.

The third aspect is that the discussion will be a permanent parallel between the two views of the market, because we believe that in this way we can prove much better the qualities and errors of each one.

We have seen that the neoclassical monopoly definition incriminates the monopolist, because he will abuse of its dominant position on the market. (Kwoka \& White, 2009, pp. 9)We thus proceed to the first fundamental question: How do we define the dominant position on the market? For example, the Romanian competition law points two important moments as references for the so-called relevant market in the case of economic concentrations ${ }^{2}$ :

- "two or several parties involved in the economic concentration operate on the same product market and as a result of concentration their market share exceeds 15\% (horizontal relations)"

- "one or several involved parties operate on a product market located upstream or downstream to any other market where other involved parties exist, and, additionally, their individual or combined market share is at least $25 \%$, disregarding whether there is or not a supplier-customer relation between the parties participating in the economic concentration (vertical relations)"

But what is the economic justification of these market shares? Are those simple numbers or it is a theory behind the regulations of the Competition Council? We can further ask if it is really a problem, for example, if some economic concentrations exceed the legal limits. The supplier of a product is not naturally conditioned by a certain market share, and that's how the Council justifies its regulations. The imminence of such a situation involving a large monopoly or cartel with large market shares which will bring severe losses to consumers constitutes the formal justification for the need of government intervention. But is this really a problem? More exactly, who suffers from this? What is to be said with the help of economic theory?

Also, almost all the mainstream views on competition and the regulations are describing the world markets as ideal states with numerous participants (atomistic view) and diversity. (Blaug, 1992, pp. 166) But these ends can't be put into practice by a law, but by the acceptance of the general public, the consumers which by their preferences determine structure modifications of the market and its participants. If there is any important element which should be included in any legal wording of the monopoly and the monopoly price, it is the consumer with his economic power.

Given all the above mentioned, we will clarify herein below three important aspects of the monopoly and the monopoly price problem:

1. Who is the monopolist and whether is to be blamed

2. What is the monopoly price?

3. Who are the "victims" of the monopoly and how can the losses be measured?

\section{The monopolist as the greatest evil of the mainstream competition theory}

Neoclassicism argues that the monopolist is the sole seller of a good. But this definition is a very limited one, because one way or another, if we apply it universally, then we can consider that

${ }^{2}$ Competition Law no. 21/1996, available at

http://www.competition.ro/documente/guidelines_on_relevant_market_definition_17342en.pdf 
all of us are to a certain extent, monopolists. I am the only seller of a unique work meaning that no other person can reproduce it precisely, thus being a different good from the good of my colleagues, and therefore I may be treated as a monopolist. This definition of monopoly as the unique seller of a certain good is not important for our purposes because it is the least problematic. (Rothbard, 2004, pp. 662; Stamate, 2009) Anyone can sell his goods on the market as long as there is a demand for them, and there is no reason to incriminate such person for delivering public goods to the satisfaction of the consumers, on a contractual basis. Even if he would be the only seller of a good $\mathrm{X}$, this situation can't be permanent, because high profits will attract other sellers from other markets. (Salerno, 2005; Costea, 2006, pp.97) If a firm is the only seller of a certain good on the market, which in neoclassical view would be called a monopoly, it should be noted that this will be a monopoly strictly committed to the same forces of the market, as any other firm. The neoclassical theory states that any restriction on the output sold and consequently the price increase in the case of a sole seller of a unique good can be incriminated as a monopoly power and an abuse of dominant position. But one of the fundamental laws of economics provides that when the prices go up, the demand goes down. So the consumers which, according to the neoclassical theory, will be hurt by the actions of the monopoly will be tempted to find substitutes for the monopolized good.

The power of the monopolist is not unlimited, because a higher price corresponds to a less contracted quantity (Costea, 2006, pp. 75)

In this case, is it not inexact to suppose a long living welfare of the monopolist? (If he acts like a neoclassical monopolist, which means restricting the output and increasing the price) Are not the economic laws immutable and universal? We believe they are, and the monopoly problem makes no different case; the supply and demand curves associated to the monopolist should be reconsidered. Neoclassical authors hold that the market should be in a permanent equilibrium (a situation impossible to determine on the market) and that the monopolist has a negative impact on this equilibrium. But

...in judging the monopoly problem, the neoclassical theory uses as standard the perfect and pure competition, where in reality the entrepreneurial function disappears (Costea, 2006, pp. 76)

A severe critique of the perfect market in equilibrium is that it can't explain the formation of prices since the equilibrium is not a realist supposition. (Rothbard, 2004, pp. 282) Moreover, it can't be even named equilibrium, but more precisely a state in which at some moment $t$ a number of entrepreneurs is to be found. (Armentano, 1999, pp. 26) The fact that the transactions are permanent, the owners of the resources are changing and so the products, confirms that we are dealing with a permanent resizing of the market, and in no case with an equilibrium state. As Hayek says

That in conditions of real life the position even of any two producers is hardly ever the same is due to facts which the theory of perfect competition eliminates by its concentration on a long-term equilibrium which in an ever changing world can never be reached" (Hayek, 1958, pp. 101)

Thus the absence of this neoclassical Walrasian state of equilibrium invalidates theoretically and practically the monopoly concept, because it can't be scientifically defined and explained. ${ }^{3}$ Monopoly is also described as a special privilege granted by the State. Murray Rothbard agrees with

\footnotetext{
3 "Enthusiasm for perfect competition in theory and the support of monopoly in practice are indeed surprisingly often found to live together" (Hayek, 1958, p.102)
} 
this definition of monopoly and believes that this is the only situation in which the concept makes sense in theory but also in practice. Other authors deliver empirical evidences maintaining that it is

impossible to identify even a sole example of monopoly which subsisted without official protection (Ballve, 1963, pp. 54)

George Reisman mentions not only that the State is the creator of the monopoly, but that the forms of its existence are extremely diverse, and delivers in his treatise a detailed presentation of the governmental interventions which contribute to the birth and growing of a monopoly. (Reisman, 1990 , pp. 377) Because the State is by definition the territorial monopoly on coercion ${ }^{4}$ it is quite clear that these interventions have no "competition" since the State can always use force to accomplish its tasks. (Hoppe, 1995) But why is the State the only entity which can support a monopoly?

We have seen that the concept of monopoly is not relevant in practice on a free market. We have no doubt that it can be used as a concept but the problem is its applicability. We consider that establishing the monopoly concept as a fundamental point for the competition theory in economic publications and moreover incriminating the monopolist on a legal basis require rapidly and efficiently a scientific support. (Armentano, 1999, pp. 15) If it is not to be found then we are entitled to invalidate the monopoly theory, as explained by neoclassical models.

We have little reasons to believe that the monopoly as described by the neoclassical theory can develop on a free market, because as every firm it is subject to the economic law regulation. This means that its actions can never be independent of the demand. The monopoly can exist in the sense of the first definition, but its incrimination is at least problematic if not dubious, since the consumer validates this state of affairs. It is the will of the consumer that puts the monopolist in rights. (Salerno, 2005) So we may restate that, if there is any authority which has the right and obligation to react in a certain way in relation to the monopolist it is the consumer. This is a fundamental thesis of the free competition theory. To suppose that an entrepreneur or association of entrepreneurs can abuse of their dominant position voluntarily confirmed by the consumers is to say that either they are careless in relation with the demand (case in which the consumers will react), or that they are indifferent to the market constraints because of the stimuli created by the government intervention. For example, let's suppose that an entrepreneur $\mathrm{X}$ is selling his product below costs, and thus damages his competitors ${ }^{5}$. After remaining the only seller of the product on the market he raises his price. The neoclassical theory says that the price will rise up to the point where profits will be maximized and the demand will remain constant. This supposition is correct but it can't be universal. Not any entrepreneur, in any industry will find the perfect relation between price and demand in order to guarantee that his profits will be maximized. We can't make this assumption because maximizing profits is the reward for the most talented entrepreneurs, those who are capable to correctly anticipate the uncertainty. Being the only seller of a good and increasing its price do not necessarily represent the condition for this reward. A higher price and restricted output may indicate a greater preference of the entrepreneur for producing some other goods, or for leisure, as a consumer good. (Salerno, 2005) The problem appears where neoclassicists make this assumption: the abuse of dominant position means raising the price unjustifiably. But we may ask who decides what and how much is justified? Which are the criteria used by the neoclassical theory to determine

\footnotetext{
4 "A government is a territorial monopolist of compulsion — an agency which may engage in continual, institutionalized property rights violations and the exploitation — in the form of expropriation, taxation and regulation — of private property owners"; also available in Romanian at http://mises.ro/249/

${ }^{5}$ Which is unfortunate of course, but he can't be incriminated because he only uses his property in regard to his own needs. If we incriminate this fact, then the consistency principle will force us to incriminate even the situations when a person, by virtue of his own intellectual abilities, using freely his intellectual property, succeeds by his own efforts to outrival his colleagues, winning a Nobel Prize and having his works published more often. Can we incriminate Professor Krugman for using his own intellectual capacity to win a Nobel Prize and outrivaling his colleagues, leaving them without the prize? We believe we can't, and this should be clear.
} 
the justness or unjustness of a price? This problem is "solved" by the neoclassical theory with the methodology of positivist empiricism which fraudulently allows measuring the utility. (Samuelson, 1937) According to the positivist agenda, the utility is an objective concept and can be measured (can take cardinal values); this will bring important outcomes on a social scale, because it can give the public policies the possibility to choose between one good or another to be delivered to the society. When an economist or public policy maker decides between the relative importance of a certain good and another one in the economy, he must make interpersonal comparisons of utility, which according to the Austrian view of the market (the theory of free competition) is impossible because of the very nature of utility, an ordinal concept. The neoclassicists can only speak about the justness of a price if they somehow know the preference scales of the consumers and entrepreneurs. This scale is a subjective one, and according to the subjective theory of value (a providential idea of the marginal revolution) no outside observer can measure the utility of a person $\mathrm{X}$ when acting. (Stamate, 2011) From this impossibility derives the fact that no observer other than the person involved can make assumptions on the justness of a price or the efficiency of a policy and its welfare effects. In this context, the dominant position theory should be restated. The dominance of an entrepreneur lies in the support of the consumers, and thus it is a legitimate action.

Another aspect of the neoclassical monopoly theory is its systematic avoidance to apply the dumping principle in a situation of monopoly. Almost unexplainable, the dumping problem disappears once the monopolist is put in his rights. Is this an economic assumption? We have no reason to believe so, since a free market means free entry. There are no scientific arguments for asserting that a new firm cannot penetrate the monopolized market.

The economic theory does not validate the premises of the neoclassical view of monopoly, and we saw why. Thus a monopolist can be at any moment outrivaled by another competitor or even by his own consumers through their substitution power. But the State monopoly or the monopoly granted by the State is not as harmless as the private one, which can develop on a free market. Taking into consideration the nature of the State, a State or State-granted monopoly can be only an impediment for the competition, and this is because the State can always load funds (as opposed to a firm which functions on a economic calculus or profit and loss basis) and adopt restrictions, for protecting its firms. Loading funds (State aids and/or subsidies) to a monopoly means expropriating other owners of resources. Also, granting licenses or even the privilege of being the only seller of a good has the negative effect of preventing other firms to innovate new products, and on the other hand of keeping the protected firms in a state of indolence and eventually idleness, having no reason to compete or satisfy the needs of the consumers. A private firm can't be a serious competitor to a State-owned firm because the profit and loss system of both firms is different. A private firm can't permanently load funds in order to face the competition of the State.

A classical way that the State uses to create monopolies is for example the commercial policies field. The protectionism creates monopoly power. By protecting a domestic producer, this one is offered a monopolistic privilege to the detriment of his competition. (Reisman, 1990, pp. 380) But it is interesting that even when the protection is not granted to a sole producer, by simply imposing tariff and non-tariff barriers, the monopolistic privileges are put in place. Those who have imported a certain product for an $n$ sum of money, are now restricted because they can't afford to import the same quantity or any quantity at all. It is very likely that the tariffs will not demotivate all the imports, but this is not the problem. What is important is that for some categories of importers this activity becomes either very expensive or completely disappears, thus creating an incentive for the domestic producers to raise the price. If we consider the theory of free competition, we may say that imposing a tariff unnaturally determines the exit of some competitive firms, leaving their consumers with a more scarce and expensive product or even without it.

We are entitled to say that the only situation in which the neoclassical monopoly theory remains relevant is the monopoly granted by the State. Only starting from the principles of free market, private property and non-aggression can we imagine a private monopoly with the 
neoclassical effects that have been stipulated.

The only situation when monopoly makes sense is when aggression enters the scene (the government protects the monopoly through different forms of protection, for example licensing, copyright, patents and commercial protectionism) (Reisman, 1990, pp. 388)

Government interventions creating monopoly are to be found also in the monetary field (where the central banks exerts a monopoly power on coinage), national security (secret services and police), defense field (the army), roads, transports etc. Each of these industries is offering a public good, and thus enters under the incidence of the same monopoly theory. Can we consider those who offer these services as monopolists? The answer is yes, of course, for two reasons: one reason concerns the aggressive manner in which they appropriate ownership titles and the other reason according to which the competition to their detriment is strictly forbidden by law.

If the monopoly should be forbidden why limit this to the private producers and not eliminate the coercive monopoly of the central bank or the monopoly on the use of violence, which defines the $\operatorname{state}^{6}$ (Costea, 2006, pp. 100)

A third definition of monopoly, and maybe the most debated, states that a monopoly is in charge whenever the firm is selling at a monopoly price. This opens a new problem, that of defining the monopoly price.

\section{What exactly is the monopoly price?}

The monopoly price is what the neoclassical monopoly theory has to prove in practice. Because

The economic identification of the monopoly price is a necessary condition, but not sufficient for the relevance in law of this concept (Costea, 2006, pp. 100)

Thus, we see that the neoclassical monopoly theory needs a strong support for the monopoly price concept, so as to be scientifically valid and also is a part of the support theories which legitimate the government intervention on the market.

Neoclassicism states that the monopoly price would result from a reduction (unnecessary) in the output sold. The entrepreneur holds an X stock of a good and a monopoly position (it is the only seller of that good), and chooses to sell a (X-1) quantity after a long period of selling X. Having monopoly power and controlling the entire resource which is needed for producing the good, the entrepreneur can increase the price by selling less of that good. And this would be an unjust situation for the consumer, because this one would have less to buy. But this is a very questionable assumption. As we have seen, it is possible that the preference of the entrepreneur for leisure or for creating another product has taken the place of the present monopolized product. Also it is very possible that a clear distinction between the monopoly price and the competitive or market price may not be made. (Rothbard, 2004, pp. 672; Salerno, 2010) The monopolist can't know a priori what is the maximum price for his product but only from empirical observations, which is not sufficient to establish a concept of maximizing profits and much less a monopoly profit. The monopoly price can't be scientifically determined because the entrepreneurial process of making profits is a gambling game, and it is inappropriate for the economists to deliver a theory which pretends to have discovered the limits of justness and unjustness of entrepreneurs' actions on the

\footnotetext{
${ }^{6}$ And from the footnote "The consistent defendants of coercive intervention of the state on the free market, against the sole sellers of goods should admit, if they create their argumentation only on the neoclassical monopoly theory, at least one contradiction, in that they try to use a <<monopoly of legal violence >>, the State, to fight another monopoly"
} 
market. The economic theory of free competition firmly states that the only authority possessing such a theory is the consumer.

If the superior price is a consequence of output restriction, what relevance would have anymore the historical information collected through the exploratory method, as a matter of fact practiced by any entrepreneur? They reveal only past terms of trade, opened to historical interpretation, but without delivering firm information regarding future prices and much less those which would have been existed. We judge that, although the two conditions of emerging monopoly price have their own theoretical and practical relevance on the market, they are not mutually sustainable, and their simultaneous application does not help to differentiate on the free market between the market price and monopoly price (Costea, 2006, pp. 94)

Neoclassicism does not have a consistent and coherent theory of monopoly price. Neither in theory nor in practice have we had clear proofs. And we believe that the necessity of having a correct theory before incriminating the entrepreneurs' actions on the market is unquestionable.

\section{Who are the monopoly "victims"?}

Neoclassical monopoly theory along with the competition laws of the governments around the world agrees that the consumer is the supposed victim of the monopoly. (Pelkmans, 2003, pp. 228) But at this stage, we should make a clear distinction between the private monopoly which can evolve on a free market and the State or State-granted monopoly which can evolve on a regulated market.

If we suppose its conceptual existence, the private monopoly is a firm like any other, dependent upon the consumer preferences, and we can't bring a lawsuit against it for its simple existence because it does not infringe the private property rights. An aggression is when an entrepreneur forces his consumers to buy his products against their will. If the consumers voluntarily buy the product, according to the economic theory of free competition there is no aggression. A law against the monopoly price and the monopolist itself must be based on a clear aggression and consumer's harm. It is true that the monopolist price may be a prohibitive one, but this would not be a satisfactory situation for the monopolist because the demand will fall. Also, it is needless to say that as a principle the consumer, as buyer, will always want lower prices or even no prices, and the seller higher prices. Given this, it is difficult to formulate a theory of the "perfect price" for both the consumer and the seller. Economic science does not deal with the perfect, just or unjust prices but with the market prices, voluntarily agreed on the market between buyers and sellers. Thus we can't argue that a private monopoly would harm the consumers.

And to prove the harm suffered by the consumer, we must first of all identify quantitatively the utility of the good; however we have already stated that utility is not a cardinal measure but an ordinal one. This brings us to the conclusion that a prospect private monopoly would be inoffensive and it would always be in danger because of other pretenders. The only thing left to say is that if they feel under-privileged, the consumers have two solutions: the substitution (a difficult option if the demand is elastic) and the boycott. Both solutions bring losses to the monopolist, which, in case of mismatching will leave the place for some other competitors. At the same time, it has to be mentioned that

passive agreement of a high price, without hostilities on the part of the consumer, proves that there is no dissatisfaction among them, and if the transaction is being made, the exchange price at that moment is the best possible price, it is the market price ${ }^{7}$ (Stamate, 2009)

\footnotetext{
7 "if no one saw any chance of improving his income without resorting to aggression, it would evidently be absurd to see anything wrong with such a super-monopoly. Should it indeed ever come into existence within the framework of a market economy, it would
} 
The case of the State or State-granted monopoly is different. Being based on coercion, a State monopoly has truly a long living life than a private one. State monopoly can change negatively the consumer preferences and their substitution rate. The ways to access the substitution products are much more troublesome. State monopoly is a long-lasting project because it is based on coercion, and has much more possibilities to change the demand structure and the incentives. A State-protected firm, although it is not functioning with public capital, can always abuse of its position on the market because the competition is kept away. In many cases, the State does not have an express intention to create or support monopolies but this is not necessary. Because it possesses the territorial monopoly on aggression and coercion, it is clear that anything with its stamp is a monopoly itself. The very difference between a State monopoly and private monopoly is that the former has a perennial nature and the latter an ephemeral one.

\section{Final conclusions}

This paper gives a clue for the correct interpretation of free competition theory, a product developed by the Austrian School of economics and a serious competitor for the mainstream (neoclassical) theory of competition. The case of the neoclassical monopoly theory needs a review. There are not sufficient reasons to believe that the concepts of monopoly, abuse of dominant position and monopoly price have profound theoretical backgrounds. As long as the monopoly price can't be scientifically proved, the entire monopoly theory is in serious question regarding its analytical and legal relevance. This is the first major critique of the present paper. For implementing the concept of monopoly in positive law and thus to be able further to create competition policies, a "severe" condition must be fulfilled: the monopoly concept must be operational. Conceptual realism - which can be found in assumptions like the monopoly price, equilibrium and continuity - may be a good premise for ideal States but in reality we need operational concepts. This is the major problem of the monopoly theory and also of the general theory of perfect and pure competition. We can argue and agree with the fact that the whole equilibrium paradigm which penetrated economic science through the tremendous influence of Léon Walras, it is useful as analytical tool to understand the objective reality, but it is inappropriate when the reality itself is equilibrium.

Another important aspect which the present paper tried to reach is the indisputable fact that there is no consensus among theorists regarding the monopoly and competition issues. As could be seen in the argumentation, two different schools of thought dedicated their theories to the competition field (neoclassical and Austrian). But if both of them hold the same purposes when describing the goodness and badness of competition, then we can be sure that they can't be simultaneously right. Thus only one can be a "candidate" for the position of truthfulness.

The only circumstance in which the monopoly theory (along with its associated theories regarding the excess capacity, social loss, misallocation etc.) is valid is in the field of State monopolies. Either owned by the State or only granted, these monopolies meet all the conditions stipulated by the neoclassical paradigm. Here we explained the fundamental difference between free competition theory and neoclassical competition theory and we argued that under the neoclassical assumptions only the State-owned or State-granted monopolies can be considered as having harmful effects on consumers. The market imperfections - the name given by the neoclassical theory to any market form which does not fulfill the conditions of perfect competition model - become true only when on the market it is instituted a compulsory monopoly on force and coercion. On a free market, no compulsory monopoly can develop if the consumer does not support it. Therefore, we can conceptually imagine a private monopoly but not independent of consumer demand and preferences. Free competition theory takes into account the possibility of a private monopoly on the market but as a temporarily state and voluntarily accepted by the consumers.

only prove that this self-same super-monopolist was indeed providing consumers with the most urgently wanted goods and services in the most efficient way" (Hoppe, 1990, p. 213) 
As a final conclusion of the paper, we must emphasize that, as economists, we have the duty to search for all possible alternative competition theories, for it is the economist views those which legitimize the economic policies. Moreover, the plea for alternative theories is crucial when the mainstream ones fail to correctly explain the economic phenomena.

\section{References}

1. Armentano Dominick T., 1999. Antitrust and Monopoly, The Independent Institute, Oakland, California

2. Ballve Faustino, 1963. Essentials of economics, D. Van Nostrand, Princeton

3. Baumol William J., Blinder Alan S., 1979. Economics: Principles and Policy, Harcourt Brace Jovanovich, Inc., New York

4. Blaug Mark, 1992. The Methodology of Economics or How Economists Explain, Second Edition, Cambridge University Press

5. Costea, Diana 2006. Activitatea antreprenorială și problema echilibrului economic în viziunea Școlii Austriece, PhD Thesis, Bucharest Academy of Economic Studies

6. Hayek Friedrich A. von, 1958. Individualism and economic order, The University of Chicago Press, Chicago

7. Hoppe Hans H., 1995. The Political Economy of Monarchy and Democracy, and the Idea of a Natural Order, Journal of Libertarian Studies, 11:2, Summer, pp. 94-121

8. Hoppe Hans H., 2010. Teoria Socialismului și a Capitalismului, Institutul Ludwig von Mises România, București

9. Kwoka John E. Jr., Lawrence White J., 2009. The Antitrust Revolution: Economics, Competition and Policy, Fifth Edition, Oxford University Press

10. Pelkmans Jacques, 200. Integrare Europeană. Metode și analiză economică, Ediția a doua, Institutul European din România

11. Reisman George, 1990. Capitalism: A Treatise on Economics, Jameson Books, Ottawa

12. Rothbard Murray N., 1978. For a New liberty: The Libertarian Manifesto, Macmillan Publishing \& Co., Inc., New York

13. Rothbard Murray N., 2004. Man, economy and state with Power and Market, The Scholar's edition, Auburn, Alabama: The Ludwig von Mises Institute, Second edition

14. Salerno Joseph T., 2005, Theory of Monopoly Price: From Menger to Rothbard, at the Austrian School of Economics: Revisionist History and Contemporary Theory seminar on June 7th, Ludwig von Mises Institute, Auburn, Alabama

15. Samuelson Paul, 1937. A Note on Measurement of Utility, The Review of Economic Studies, Vol. 4, No.2, pp. 155-161

16. Stamate, Andreas, 2009. Teoria austriacă post-misesiană a monopolului:Murray Newton Rothbard, Revista Oeconomica - Societatea Română de Economie (SOREC) - Institutul Român pentru Libera Întreprindere, Anul XVIII, nr.1

17. Stamate Andreas, 2011. A Short History of the "Just Price" Controversy in the XII-th and XII-th Centuries, The Romanian Economic Journal, Year XIV, no. 39 